\title{
Resistance to Stripe Rust in Five Durum Wheat Cultivars
}

\author{
Hong Ma, former Postdoctoral Fellow, Ravi P. Singh, Geneticist/Pathologist, and Osman Abdalla, former Durum \\ Wheat Breeder, International Maize and Wheat Improvement Center (CIMMYT), Lisboa 27, Apdo. Postal 6-641, \\ 06600 Mexico, D.F., Mexico
}

\begin{abstract}
Ma, H., Singh, R. P., and Abdalla, O. 1997. Resistance to stripe rust in five durum wheat cultivars. Plant Dis. 81:27-30.

Durum wheat (Triticum turgidum) cultivars developed by the International Maize and Wheat Improvement Center (CIMMYT) are currently grown on more than 8 million hectares worldwide. Because of the lack of information on the genetic basis of resistance to stripe rust (caused by Puccinia striiformis), crosses in a diallel arrangement (without reciprocals) were made among five worldwide resistant cultivars and the susceptible cultivar Local Red. Inheritance of resistance was investigated in seedling and adult plant growth stages of $F_{2}$ populations, and $F_{3}$ lines. The low seedling infection type of each resistant cultivar, namely Kroub 76, Chonta Inia, Sna 3, Syros, and Arena, was based on the additive action of the same two genes. Each of these genes conferred intermediate infection types when present alone. The field resistance of the cultivars was based on the additive action of the two genes identified in the seedlings and one additional, partially effective adult resistance gene. Segregation for plants with stripe rust severities higher than that of the parents in intercrosses of resistant cultivars indicated that some genetic diversity exists for adult genes. The resistance of these cultivars may prove to be longlasting, since it results from the combined action of at least three genes.
\end{abstract}

Durum wheat (Triticum turgidum L.) is grown on approximately 17 million hectares (2), mostly in the Middle East, North Africa, the Indian subcontinent, and Mediterranean Europe. Other areas include parts of Ethiopia, Argentina, Chile, Mexico, the United States, and Canada. Stripe rust (caused by Puccinia striiformis Westend.) is an important disease that can cause significant losses to durum production in cool and humid regions $(23,24)$. Frequent stripe rust epidemics have been reported in Iran (4), Yemen, Egypt, and Turkey (23). Although a few cultivars in India are known to be resistant to the disease, the area under durum wheat cultivation may have greatly diminished, partly because most cultivars are highly susceptible (24). Durum wheat germ plasm has been evaluated for stripe rust resistance in various countries, and resistant sources have been reported in land races from Israel (26) and Jordan (13). Mamluk (23) tested 216 durum cultivars in the field and found that $32 \%$ were resistant. We have observed a wide range of seedling and adult resistance to stripe rust in cultivars from various countries (H. Ma, R. P. Singh, and O. Abdalla, unpublished). Multilocational testing of advanced breeding lines is an integral part of the durum wheat

Corresponding author: R. P. Singh
E-mail: rsingh@cimmyt.mx

Accepted for publication 23 September 1996.

Publication no. D-1996-1022-04R

(C) 1997 The American Phytopathological Society improvement program at the International Maize and Wheat Improvement Center (CIMMYT). Such evaluation exposes germ plasm to a wide array of races of $P$. striiformis and aids in the identification of parents with worldwide resistance. Results of the international screening nurseries indicate that the level of resistance to stripe rust for CIMMYT durum germ plasm has increased in recent years; this improved resistance is believed to be due to the accumulation of several resistance genes (1). However, information on the inheritance and genetic diversity of stripe rust resistance in durum wheats is limited, and almost nonexistent for CIMMYT durums that are grown on a large area worldwide. Macer (22) identified major gene $\mathrm{Yr}$, which confers seedling resistance in the land race Iumillo. However, this gene is not effective against $P$. striiformis races present in Mexico and most other countries (15). Minor genes with additive effects have also been reported in durums (18). Triticum dicoccoides, an ancestor of cultivated durum wheat, possesses useful stripe rust resistance that is controlled by major $(8,11)$, minor $(8,30)$, or temperature-sensitive genes $(9,10)$.

The objectives of the current study were to determine (i) the genetic basis of stripe rust resistance in seedlings and adult plants of five worldwide resistant durum wheat cultivars, and (ii) the relationship of the genes involved in the resistance of these cultivars.

\section{MATERIALS AND METHODS}

The five resistant durum wheat cultivars included in the study were Kroub 76,
Chonta Inia, Sna 3, Syros, and Arena (Table 1). Kroub 76, Chonta Inia, Sna 3, and Syros originated from CIMMYT's durum wheat breeding program and have been released in different countries. The pedigree of the Italian cultivar Arena is not known; however, it may also be of CIMMYT origin. The five resistant parents have also shown high levels of stripe rust resistance when tested internationally in CIMMYT's International Durum Screening Nurseries for several years (5-7).

The $P$. striiformis race used in all studies was 14E14 (16), which is virulent to stripe rust resistance genes $Y r 2,3,6,7$, and $A$. Race 14E14 is the predominant race in the highlands of Mexico, where the studies were conducted. Vacuum-dried (32) urediniospores of this race are stored at CIMMYT. Fresh inoculum obtained by multiplying urediniospores on the susceptible cultivar Morocco was used in the study.

Crosses were made among resistant durums in a diallel arrangement without reciprocals. Resistant durums were also crossed with the susceptible female parent Local Red. Inheritance studies were based on $F_{2}$ populations, and individual $F_{2}$-plantderived $\mathrm{F}_{3}$ lines were obtained from two or three individual $F_{1}$ plants. Disease data for $\mathrm{F}_{1}$ plants are not available because they were grown during the off-season.

Between 188 and $338 \mathrm{~F}_{2}$ seedlings, as well as 115 and 180 individual $F_{2}$-plantderived $\mathrm{F}_{3}$ lines, from crosses of Local Red with five resistant parents, were classified at the seedling stage for their infection types. Individual $\mathrm{F}_{3}$ family size consisted of 30 to 40 seedlings. Between 108 and $253 \mathrm{~F}_{2}$ seedlings from each intercross involving resistant parents were also evaluated. Nine-day-old seedlings of the parents, $\mathrm{F}_{2}$, and $\mathrm{F}_{3}$ lines, were inoculated by spraying urediniospores suspended in Soltrol 170, a lightweight mineral oil, at a concentration of approximately 4 to 5 $\mathrm{mg} / \mathrm{ml}$. After inoculation, plants were placed in a dew chamber for $18 \mathrm{~h}$ at 10 to $14^{\circ} \mathrm{C}$ and then transferred to the greenhouse under 16-h light and 8-h dark photoperiod and 15 to $20^{\circ} \mathrm{C}$ temperature. Inoculation was repeated 3 days later to avoid any escape. Infection type (IT) data based on a 0 to 9 scale (20) were recorded approximately 3 weeks after inoculation.

For susceptible $\times$ resistant crosses, frequencies of the $F_{2}$ seedlings rated as resistant (IT 0 to 3 , no visible symptoms to necrotic and/or chlorotic blotches or stripes with trace sporulation) and intermediate 
(IT 4 to 6, necrotic and/or chlorotic blotches or stripes with light to moderate sporulation) were pooled for the chi-square analyses. The susceptible group included all seedlings rated as IT 7 to 9 (slightly necrotic and/or chlorotic blotches or stripes with abundant sporulation to abundantly sporulating blotches or stripes with no chlorosis or necrosis). The $\mathrm{F}_{3}$ lines were grouped into three categories, namely, homozygous parental type resistant (all resistant parent), segregating-intermediate (ITs of the seedlings ranging from resistant to intermediate, resistant to susceptible, intermediate to susceptible, or homozygous intermediate), and homozygous parental type susceptible (all seedlings with ITs within the range of the susceptible parent). Chi-square analyses were carried out to test the distribution of observed $\mathrm{F}_{2}$ and $\mathrm{F}_{3}$ phenotypic frequencies against those expected for a two-gene segregation model.

Field evaluations of parents and $F_{2}$ populations from the resistant $\times$ resistant crosses were conducted at CIMMYT's research station near Toluca, Mexico State, during the 1994 crop season. Approximately $150 \mathrm{~F}_{2}$ seeds from each cross were planted $20 \mathrm{~cm}$ apart in three $75-\mathrm{cm}$-wide paired row plots of 5-m length. Spreader rows of cultivar Morocco were sown down the middle of the 1-m pathway on both sides of the plots. Ninety $F_{3}$ lines from seedlings with ITs within the range of the

each of the resistant $\times$ resistant crosses and between 115 to 180 lines from the susceptible $\times$ resistant crosses were grown at INIFAP's (National Forestry, Agriculture and Livestock Research Institute) research station near Celaya (Guanajuato State) during the 1994-95 season. Approximately 60 seeds of each $\mathrm{F}_{3}$ line were sown in 75$\mathrm{cm}$-wide paired row plots of 1-m length with $20-\mathrm{cm}$ row spacing and a $50-\mathrm{cm}$ pathway between plots. Rows of the two parents were planted at the beginning of each $\mathrm{F}_{3}$ population. The stripe rust epidemic was initiated approximately 1 month after sowing by inoculating spreader rows of Morocco planted on one side of the plots in the pathway. Both field sites, namely Toluca and Celaya, are located in the highlands and have a favorable environment for stripe rust development. Disease severity of each $F_{2}$ plant was rated following the Modified Cobb Scale (27) when plants of the susceptible check Local Red displayed 80 to $100 \%$ severity. Severity range for each $F_{3}$ line was recorded twice; first when the susceptible parent Local Red had 80 to $100 \%$ severity and approximately 2 weeks later when stripe rust had dried out the leaves of Local Red. Previous studies at CIMMYT (39) showed that the timing of the first rating is critical for identifying plants or lines that are similar in susceptibility level to the susceptible parent; whereas the second rating

Table 1. Durum wheat cultivars, country of release, seedling infection type with Puccinia striiformis race 14E14, and adult ratings with the same race at two locations

\begin{tabular}{|c|c|c|c|c|}
\hline \multirow[b]{2}{*}{ Parent } & \multirow{2}{*}{$\begin{array}{l}\text { Country } \\
\text { of release }\end{array}$} & \multirow{2}{*}{$\begin{array}{c}\text { Seedling } \\
\text { infection type }^{a}\end{array}$} & \multicolumn{2}{|c|}{ Adult rating ${ }^{b}$} \\
\hline & & & Toluca 1994 & Celaya 1994-95 \\
\hline Kroub 76 & Algeria & 1 to 2 & $5 \mathrm{MR}$ & $5 \mathrm{MR}$ \\
\hline Chonta Inia & Chile & 0 to 2 & $1 \mathrm{MR}$ & $5 \mathrm{MR}$ \\
\hline Sna 3 & Chile & 1 to 3 & $5 \mathrm{MR}$ & $5 \mathrm{MR}$ \\
\hline Syros & Greece & 1 to 3 & $5 \mathrm{MR}$ & $5 \mathrm{MR}$ \\
\hline Arena & Italy & 1 to 2 & $5 \mathrm{MR}$ & $5 \mathrm{MR}$ \\
\hline Local Red & India & 7 to 9 & $100 \mathrm{~S}$ & $100 \mathrm{~S}$ \\
\hline
\end{tabular}

${ }^{a}$ Based on a 0 to 9 scale (20), where $0=$ no visible symptom, $1=$ necrotic and/or chlorotic flecks without sporulation, $2=$ necrotic and/or chlorotic blotches or stripes without sporulation, $3=$ necrotic and/or chlorotic blotches or stripes with trace sporulation, $7=$ necrotic and/or chlorotic blotches or stripes with abundant sporulation, $8=$ chlorosis behind the abundantly sporulating area, and $9=$ abundant sporulation with no chlorosis or necrosis.

${ }^{\mathrm{b}}$ Rating includes two components: disease severity based on the Modified Cobb Scale (27), where 1 $=1 \%, 5=5 \%$, up to $100=100 \%$; and host response based on scale described by Roelfs et al. (32), where $\mathrm{MR}=$ moderately resistant and $\mathrm{S}=$ susceptible. time is critical for identifying plants or lines that are similar in resistance level to the resistant parent. On the basis of the two data sets, $F_{3}$ lines from the susceptible $x$ resistant crosses were grouped into three categories as described earlier for seedling studies. Chi-square analyses were again carried out.

\section{RESULTS}

Seedling studies. Seedlings of all five resistant parents displayed low infection types compared to the susceptible parent Local Red when tested with P. striiformis race 14E14 (Table 1). Chonta Inia had the lowest IT range, followed by Kroub 76, Arena, Sna 3, and Syros.

$\mathrm{F}_{2}$ populations from crosses of Local Red with five resistant parents segregated for seedlings with a range of resistant, intermediate, and susceptible ITs (Table 2). Frequencies of seedlings considered to have some resistance (ITs between 0 and 6) versus those considered to be susceptible (ITs between 7 and 9) were in accordance with a 15:1 ratio for each cross. This ratio is expected for segregation of two partially dominant resistance genes. The distribution of $\mathrm{F}_{3}$ lines in each cross conformed to a ratio of 1 homozygous parental type resistant to 14 segregating-intermediate to 1 homozygous parental type susceptible, expected for segregation of two genes having additive action. Intermediate ITs were observed when resistance genes were present alone.

$\mathrm{F}_{2}$ populations obtained from the intercrosses of resistant parents had some seedlings with slightly higher ITs than those of the parents (Table 3). Lack of seedlings with susceptibility (IT 7 to 9) indicated that the resistant parents may carry at least one common gene.

Field studies. The resistant parents showed a high level of resistance in field tests at both locations (Table 1). The maximum disease recorded was $5 \mathrm{MR}$ for each resistant parent, compared to $100 \mathrm{~S}$ for Local Red.

Comparison of seedling and adult reactions of the $\mathrm{F}_{3}$ lines from crosses of Local Red with the five susceptible parents is given in Table 4. Only a few lines classified as homozygous parental type resistant

Table 2. Seedling classification and chi-square analysis of $F_{2}$ populations and $F_{3}$ lines in the crosses of susceptible Local Red with resistant durums inoculated with Puccinia striiformis race 14E14

\begin{tabular}{|c|c|c|c|c|c|c|c|c|c|}
\hline \multirow[b]{3}{*}{ Cross } & \multicolumn{4}{|c|}{$\mathbf{F}_{2}$} & \multicolumn{5}{|c|}{$\mathbf{F}_{3}$} \\
\hline & \multicolumn{2}{|c|}{ No. of seedlings ${ }^{\mathrm{a}}$} & \multirow{2}{*}{$\begin{array}{l}\chi^{2} 15: 1 \\
P \text { value }\end{array}$} & \multirow{2}{*}{$\begin{array}{c}\text { Estimated } \\
\text { gene no. }\end{array}$} & \multicolumn{3}{|c|}{ No. of lines ${ }^{b}$} & \multirow{2}{*}{$\begin{array}{c}\chi^{2} 1: 14: 1, \\
P \text { value }\end{array}$} & \multirow{2}{*}{$\begin{array}{c}\text { Estimated } \\
\text { gene no. }\end{array}$} \\
\hline & R/Int & $\mathbf{S}$ & & & HPTR & Seg/Int & HPTS & & \\
\hline Local Red $\times$ Kroub 76 & 185 & 14 & $0.2, P>0.50$ & 2 & 9 & 94 & 12 & $4.5, P>0.10$ & 2 \\
\hline Local Red $\times$ Chonta Inia & 174 & 14 & $0.2, P>0.50$ & 2 & 15 & 151 & 14 & $2.6, P>0.25$ & 2 \\
\hline Local Red $\times$ Sna 3 & 322 & 16 & $1.0, P>0.25$ & 2 & 14 & 152 & 14 & $1.9, P>0.25$ & 2 \\
\hline Local Red $\times$ Syros & 224 & 12 & $0.4, P>0.50$ & 2 & 9 & 99 & 9 & $1.3, P>0.50$ & 2 \\
\hline Local Red $\times$ Arena & 230 & 16 & $0.0, P>0.99$ & 2 & 10 & 154 & 16 & $2.5, P>0.25$ & 2 \\
\hline
\end{tabular}

${ }^{\mathrm{a}} \mathrm{R} / \mathrm{Int}=$ resistant-intermediate (IT 0 to 6 ), $\mathrm{S}=$ susceptible (IT 7 to 9).

${ }^{\mathrm{b}}$ HPTR = homozygous parental type resistant, ITs of seedlings within the range of the IT of the resistant parent; Seg/Int = segregating-intermediate, ITs of seedlings in a family range from resistant to intermediate, resistant to susceptible, intermediate to susceptible, or homozygous intermediate; HPTS = homozygous parental type susceptible, ITs of seedlings within the range of the IT of the susceptible parent. 
(HPTR) as seedlings were HPTR in the field. The remaining lines either segregated for plants with somewhat higher (up to 30MR reaction) disease levels or were homozygous for plants with somewhat higher disease levels. $\mathrm{F}_{3}$ lines classified as segregating-intermediate (Seg/Int) were also $\mathrm{Seg} / \mathrm{Int}$ in field tests. $\mathrm{F}_{3}$ lines classified homozygous parental type susceptible
(HPTS) as seedlings were either HPTS in the field, or segregated, or homozygous for plants with intermediate responses (40 to 60MR). Distribution of $F_{3}$ lines in each cross-conformed with the ratio expected for segregation of three independent resistance genes (Table 4). Two of these genes also conferred seedling resistance; whereas an additional gene was involved in adult

Table 3. Distribution of $\mathrm{F}_{2}$ seedlings by infection types in resistant $\times$ resistant crosses infected with Puccinia striiformis race 14E14

\begin{tabular}{|c|c|c|c|c|c|c|}
\hline \multirow[b]{2}{*}{ Cross } & \multicolumn{5}{|c|}{ No. of $F_{2}$ seedlings with infection type ${ }^{a}$} & \multirow[b]{2}{*}{ Total } \\
\hline & $\mathbf{0}$ & 1 & 2 & 3 & 4 & \\
\hline Kroub $76 \times$ Chonta Inia & 15 & 25 & 70 & $36^{* \mathrm{~b}}$ & $5^{*}$ & 151 \\
\hline Kroub $76 \times$ Sna 3 & 0 & 20 & 40 & 40 & $8^{*}$ & 108 \\
\hline Kroub $76 \times$ Syros & 0 & 77 & 121 & 40 & $2^{*}$ & 240 \\
\hline Kroub $76 \times$ Arena & 0 & 49 & 141 & $43^{*}$ & $4^{*}$ & 237 \\
\hline Chonta Inia $\times$ Sna 3 & 45 & 62 & 81 & 35 & $14^{*}$ & 251 \\
\hline Chonta Inia $\times$ Syros & 59 & 70 & 91 & 31 & $2 *$ & 253 \\
\hline Chonta Inia $\times$ Arena & 11 & 13 & 82 & 91 & $7 *$ & 204 \\
\hline Sna $3 \times$ Syros & 0 & 11 & 68 & 131 & $19^{*}$ & 229 \\
\hline Sna $3 \times$ Arena & 0 & 10 & 65 & 127 & $33^{*}$ & 235 \\
\hline Syros $\times$ Arena & 0 & 13 & 71 & 42 & $2^{*}$ & 128 \\
\hline
\end{tabular}

${ }^{a}$ Based on a 0 to 9 scale (20), where $0=$ no visible symptom, $1=$ necrotic and/or chlorotic flecks without sporulation, $2=$ necrotic and/or chlorotic blotches or stripes with trace sporulation, $3=$ necrotic and/or chlorotic blotches or stripes with trace sporulation, and $4=$ necrotic and/or chlorotic blotches or stripes with moderate sporulation.

${ }^{\mathrm{b}}$ Infection type of the seedlings higher than the parental range.

Table 4. Seedling and field responses of $\mathrm{F}_{3}$ lines from the crosses of Local Red with the resistant parents when inoculated with Puccinia striiformis race 14E14

\begin{tabular}{|c|c|c|c|c|c|c|}
\hline \multicolumn{2}{|c|}{ Response $^{\mathrm{a}}$} & \multicolumn{5}{|c|}{ No. of $F_{3}$ lines when crossed with Local Red } \\
\hline Seedling & Field & Kroub 76 & Chonta Inia & Sna 3 & Syros & Arena \\
\hline HPTR & HPTR & 2 & 3 & 2 & 2 & 3 \\
\hline HPTR & Seg/Int & 7 & 12 & 12 & 7 & 10 \\
\hline HPTR & HPTS & 0 & 0 & 0 & 0 & 0 \\
\hline Seg/Int & HPTR & 0 & 0 & 0 & 0 & 0 \\
\hline Seg/Int & Seg/Int & 94 & 151 & 152 & 99 & 154 \\
\hline Seg/Int & HPTS & 0 & 0 & 0 & 0 & 0 \\
\hline HPTS & HPTR & 0 & 0 & 0 & 0 & 0 \\
\hline HPTS & Seg/Int & 8 & 9 & 10 & 6 & 8 \\
\hline HPTS & HPTS & 4 & 5 & 4 & 3 & 6 \\
\hline \multirow{4}{*}{\multicolumn{2}{|c|}{$\begin{array}{l}\text { Total } \\
\chi^{2} \text { 1:3:0:0:56:0:0:3:1 } \\
P \text { value }\end{array}$}} & 115 & 180 & 180 & 117 & 180 \\
\hline & & 4.96 & 2.55 & 1.93 & 1.65 & 3.27 \\
\hline & & $>0.75$ & $>0.90$ & $>0.90$ & 0.99 & $>0.90$ \\
\hline & & 3 & 3 & 3 & 3 & 3 \\
\hline
\end{tabular}

${ }^{\text {a }}$ HPTR = homozygous parental type resistant, responses of plants within the range of the resistant parent; Seg/Int = segregating-intermediate, responses of plants within a family range from resistant to intermediate, resistant to susceptible, intermediate to susceptible, or homozygous intermediate; HPTS $=$ responses of plants within the range of the susceptible parent. resistance. Although this adult resistance gene conferred only moderate resistance when present alone, it must have enhanced the effects of the seedling resistance genes to confer the high levels of adult resistance seen in the cultivars.

The $\mathrm{F}_{2}$ and $\mathrm{F}_{3}$ results for intercrosses involving the resistant parents are summarized in Table 5. A few plants in each cross displayed stripe rust severities higher than the parents; however, none were as susceptible as Local Red. This indicated that the resistant parents probably have at least one resistance gene in common. Ninety $\mathrm{F}_{3}$ lines from each cross were also evaluated to verify $F_{2}$ results (Table 5). Although limited segregation was observed in each cross, the highest stripe rust severity for plants in any line was $30 \%$ or less. $\mathrm{F}_{3}$ lines from crosses of Chonta Inia with Sna 3, Syros, or Arena had the least variation for disease severity; the highest severity recorded was $10 \%$. Overall results indicated that at least one or two genes are common in the resistant parents.

\section{DISCUSSION}

Two resistance genes were involved in the seedling resistance of each of five worldwide resistant durum wheat cultivars when the cultivars were tested with $P$. striiformis race 14E14. These genes appeared to confer an intermediate infection type (IT 4 to 5) when present alone. The combination of these two genes resulted in lower ITs (0 to 3 ) characteristic of the resistant parents, indicating that the two genes complemented each other (Table 2). This was supported by the fact that only a few (1/16) $\mathrm{F}_{3}$ lines were as resistant as the resistant parent, and similarly, that the same proportion of lines was as susceptible as the susceptible parent (Table 2). Additive gene action is known for rust resistance genes that confer intermediate seedling infection types $(17,33,34,36)$. Limited segregation in intercrosses of the resistant parents indicated that these durums share common resistance genes. Although the five durum parents have been released in four different countries, they are derived from CIMMYT germ plasm. This explains their limited, or lacking, genetic diversity for seedling re-

Table 5. Field responses of $\mathrm{F}_{2}$ and $\mathrm{F}_{3}$ populations in the resistant $\times$ resistant crosses when inoculated with Puccinia striiformis race 14E14

\begin{tabular}{|c|c|c|c|c|c|c|c|c|c|c|c|}
\hline \multirow[b]{2}{*}{ Cross } & \multicolumn{3}{|c|}{$\begin{array}{c}F_{2} \\
\text { Plants in disease severity }{ }^{\mathrm{a}} \text { range } \\
\end{array}$} & \multirow[b]{2}{*}{ Total } & \multicolumn{6}{|c|}{$\begin{array}{c}F_{3} \\
\text { Lines with plants of greatest disease severity } \\
\end{array}$} & \multirow[b]{2}{*}{ Total } \\
\hline & 0 to 5 & 10 to 15 & 20 to 40 & & 1 & 5 & 10 & 15 & 20 & 30 & \\
\hline Kroub $76 \times$ Chonta Inia & 110 & 2 & 0 & 112 & 6 & 56 & 16 & 6 & 3 & 3 & 90 \\
\hline Kroub $76 \times$ Sna 3 & 108 & 2 & 0 & 110 & 11 & 33 & 14 & 14 & 16 & 2 & 90 \\
\hline Kroub $76 \times$ Syros & 112 & 4 & 0 & 116 & 16 & 42 & 19 & 3 & 9 & 1 & 90 \\
\hline Kroub 76 × Arena & 112 & 1 & 0 & 113 & 17 & 39 & 20 & 9 & 5 & 0 & 90 \\
\hline Chonta Inia $\times$ Sna 3 & 124 & 1 & 0 & 125 & 46 & 39 & 5 & 0 & 0 & 0 & 90 \\
\hline Chonta Inia $\times$ Syros & 129 & 3 & 0 & 132 & 76 & 11 & 3 & 0 & 0 & 0 & 90 \\
\hline Chonta Inia $\times$ Arena & 117 & 5 & 0 & 122 & 73 & 13 & 4 & 0 & 0 & 0 & 90 \\
\hline Sna $3 \times$ Syros & 103 & 16 & 6 & 125 & 36 & 38 & 7 & 5 & 4 & 0 & 90 \\
\hline Sna $3 \times$ Arena & 133 & 5 & 4 & 142 & 45 & 27 & 8 & 7 & 3 & 0 & 90 \\
\hline Syros $\times$ Arena & 101 & 8 & 3 & 112 & 21 & 37 & 15 & 11 & 6 & 0 & 90 \\
\hline
\end{tabular}

a Disease severities based on Modified Cobb Scale (27), where $0=0 \%, 1=1 \%, 5=5 \%$, up to $100=100 \%$. 
sistance genes. Each cultivar also carries an additional adult resistance gene. At least some genetic diversity was evident in intercrosses of the resistant parents. Adult genes were only partially effective when present alone, but their presence increased the level of adult resistance conferred by seedling genes. Such additive action involving seedling and adult rust resistance genes has been observed in other studies $(12,37,38)$.

Despite the fact that the stripe rust resistance of these durums is currently effective all over the world, the limited genetic diversity for resistance observed in this study may be cause for concern. Earlier studies on resistance to leaf and stem rusts in selected CIMMYT durums indicated a similar situation $(36,37)$. Evaluation of stripe rust resistance of other durums of CIMMYT origin having adequate field resistance showed that several of them were only moderately resistant; whereas others were susceptible as seedlings (21; H. Ma, R. P. Singh, and O. Abdalla, unpublished). Our preliminary results (unpublished) indicated that such adult resistance is based on additive action of three to five partially effective genes. This kind of adult stripe rust resistance is quite common in hexaploid wheats $(3,14,18,19$, $25,28,29,35,40)$. Stripe rust has not yet posed a major threat to CIMMYT-derived durum cultivars. It is possible that most seedling and adult resistance genes in CIMMYT durums are only partially effective. Therefore, selection of high resistance levels in the field would indirectly enhance the accumulation of necessary seedling and adult genes that act additively. Resistances based on combinations of effective genes are likely to be longer lasting than those based on single genes (31).

\section{LITERATURE CITED}

1. Abdalla, O. 1995. Breeding durum wheat at CIMMYT. Pages 68-76 in: Wheat Breeding at CIMMYT: Commemorating 50 Years of Research in Mexico for Global Wheat Improvement. S. Rajaram and G. P. Hettel, eds. CIMMYT Wheat Special Report No. 29, CIMMYT, Mexico, D.F., Mexico.

2. Abdalla, O., Dieseth, J. A., and Singh, R. P. 1992. Breeding durum wheat at CIMMYT. Pages 1-13 in: Durum Wheats: Challenge and Opportunities. S. Rajaram, E. E. Saari, and G. P. Hettel, eds. CIMMYT Wheat Special Reports No. 9, CIMMYT, Mexico, D.F., Mexico.

3. Allan, R. E., Purdy, L. H., and Vogel, O. A. 1966. Inheritance of seedling and adult reaction of wheat to stripe rust. Crop Sci. 6:242-245.

4. Bamdadian, A. 1984. Variation in pathogenicity and evolution of Puccinia striiformis West. in Iran during 1980-84. Pages 219-222 in: Proc. Eur. Mediterr. Cereal Rusts Conf., 6 th.

5. CIMMYT. 1986. Results of the Fifteenth International Durum Screening Nursery
(IDSN) 1983-1984. CIMMYT, Mexico, D.F., Mexico.

6. CIMMYT. 1993. Results of the 1989-90 Durum Wheat Nurseries. CIMMYT, Mexico, D.F., Mexico.

7. CIMMYT. 1996. Results of the 1990-91 Durum Wheat Nurseries. CIMMYT, Mexico, D.F., Mexico.

8. Gerechter-Amitai, Z. K., and Grama, A. 1974. Inheritance of resistance to stripe rust (Puccinia striiformis) in crosses between wild emmer (Triticum dicoccoides) and cultivated tetraploid and hexaploid wheats. I. Triticum durum. Euphytica 23:387-392.

9. Gerechter-Amitai, Z. K., Sharp, E. L., and Reinhold, M. 1981. Temperature sensitive genes for stripe rust resistance in Triticum dicoccoides indigenous to Israel. (Abstr.) Phytopathology $71: 218$.

10. Gerechter-Amitai, Z. K., and van Silfhout, C. H. 1989. Race-specificity of temperature-sensitive genes for resistance to Puccinia striiformis in Triticum dicoccoides. Euphytica 43:7-14.

11. Gerechter-Amitai, Z. K., van Silfhout, C. H., Grama, A., and Kleitman, F. 1989. Yr15-a new gene for resistance to Puccinia striiformis in Triticum dicoccoides sel. G-25. Euphytica 43:187-190.

12. German, S. E., and Kolmer, J. A. 1992. Effect of gene Lr34 in the enhancement of resistance to leaf rust of wheat. Theor. Appl. Genet. 84:97-105.

13. Jaradat, A. A. 1992. Estimates of phenotypic diversity and trait associations in durum wheat landraces from Jordan. J. Genet. Breeding 46:69-76.

14. Johnson, R., 1980. Genetics of adult plant resistance to yellow rust in winter wheat cultivars. Pages 59-63 in: Proc. Eur. Mediterr. Cereal Rusts Conf., 5th.

15. Johnson, R. 1992. Past, present and future opportunities in breeding for disease resistance, with examples from wheat. Euphytica 63:3-22.

16. Johnson, R., Stubbs, R. W., Fuchs, E., and Chamberlain, N. H. 1972. Nomenclature for physiological races of Puccinia striiformis infecting wheat. Trans. Br. Mycol. Soc. 58:475480.

17. Kolmer, J. A. 1992. Enhanced leaf rust resistance in wheat conditioned by resistance gene pairs with $\operatorname{Lr13}$. Euphytica 61:123-130.

18. Krupinsky, J. M., and Sharp, E. L. 1979. Reselection for improved resistance of wheat to stripe rust. Phytopathology 69:400-404.

19. Law, C. N., Gaines, R. L., Johnson, R., and Worland, A. J. 1978. The application of aneuploid techniques to a study of stripe rust resistance in wheat. Pages 427-436 in: Proc. Int. Wheat Genet Symp., 5th. S. Ramanujam, ed.

20. Line, R. F., and Qayoum, A. 1991. Virulence, aggressiveness, evolution, and distribution of races of Puccinia striiformis (the cause of stripe rust of wheat) in North America, 196887. U.S. Dep. Agric. Tech. Bull. 1788.

21. Ma, H., Singh, R. P., and Mujeeb-Kazi, A. 1995. Resistance to stripe rust in Triticum turgidum, T. tauschii and their synthetic hexaploids. Euphytica 82:117-124.

22. Macer, R. C. F. 1966. The formal monosomic genetic analysis of stripe rust (Puccinia striiformis) resistance in wheat. Proc. Int. Wheat Genet. Symp., 2nd. Hereditas Suppl. 2:127-142.

23. Mamluk, O. F. 1992. Durum wheat diseases in
West Asia and North Africa (WANA). Pages 89-106 in: Durum Wheats: Challenge and Opportunities. S. Rajaram, E. E. Saari, and G. P. Hettel, eds. CIMMYT Wheat Special Reports No. 9. CIMMYT, Mexico, D.F., Mexico.

24. Mathur, J. B. L. 1992. Durum wheat breeding in India. Pages 44-48 in: Durum Wheats: Challenge and Opportunities. S. Rajaram, E. E. Saari, and G. P. Hettel, eds. CIMMYT Wheat Special Reports No. 9. CIMMYT, Mexico, D.F., Mexico.

25. Milus, E. A., and Line, R. F. 1986. Number of genes controlling high-temperature, adultplant resistance to stripe rust in wheat. Phytopathology 76:93-96.

26. Mishra, A. N., Verma, P. K., Brahma, R. N., Mutkekar, M. L., Paramjit, S., and Singh, P. 1989. Evaluation of Israel durum land races for rust resistance in India. Cereal Rusts Powdery Mildews Bull. 17:46-56.

27. Peterson, R. F., Campbell, A. B., and Hannah, A. E. 1948. A diagrammatic scale for estimating rust severity on leaves and stem of cereals. Can. J. Res. C. 26:496-500.

28. Pope, W. K. 1968. Interaction of minor genes for resistance to stripe rust in wheat. Pages 251-257 in: Proc. Int. Wheat Genet. Symp. 3rd. K. W. Finlay and K. W. Shepher, eds.

29. Qayoum, A., and Line, R. F. 1985. Hightemperature, adult-plant resistance to stripe rust of wheat. Phytopathology 75:1121-1125.

30. Reinhold, M., Sharp, E. L., and GerechterAmitai, Z. K. 1983. Transfer of additive "minor-effect" genes for resistance to Puccinia striiformis from Triticum dicoccoides into Triticum durum and Triticum aestivum. Can. J. Bot. 61:2702-2707.

31. Roelfs, A. P. 1988. Resistance to leaf and stem rusts in wheat. Pages 10-22 in: Breeding Strategies for Resistance to the Rusts of Wheat. N. W. Simmonds and S. Rajaram, eds. CIMMYT, Mexico, D.F., Mexico.

32. Roelfs, A. P., Singh, R. P., and Saari, E. E. 1992. Rust Diseases of Wheat: Concepts and Methods of Disease Management. CIMMYT, Mexico, D.F., Mexico.

33. Samborski, D. J., and Dyck, P. L. 1982. Enhancement of resistance to Puccinia recondita by interactions of resistance genes in wheat. Can. J. Plant Pathol. 4:152-156.

34. Schafer, J. F., Caldwell, R. M., Patterson, F. L., and Compton, L. E. 1963. Wheat leaf rust resistance combinations. Phytopathology 53:569-573.

35. Sharp, E. L., Sally, B. K., and Taylor, G. A. 1976. Incorporation of additive genes for stripe rust resistance in winter wheat. Phytopathology 66:794-797.

36. Singh, R. P., Bechere, E., and Abdalla, O. 1992. Genetic analysis of resistance to stem rust in ten durum wheats. Phytopathology 82:919-922.

37. Singh, R. P., Bechere, E., and Abdalla, O. 1993. Genetic analysis of resistance to leaf rust in nine durum wheats. Plant Dis. 77:460-463.

38. Singh, R. P., and Huerta-Espino, J. 1995. Inheritance of seedling and adult plant resistance to leaf rust in wheat cultivars Ciano 79 and Papago 86. Plant Dis. 79:35-38.

39. Singh, R. P., and Rajaram, S. 1992. Genetics of adult-plant resistance to leaf rust in 'Frontana' and three CIMMYT wheats. Genome 35:24-31.

40. Singh, R. P., and Rajaram, S. 1994. Genetics of adult plant resistance to stripe rust in ten spring bread wheats. Euphytica 72:1-7. 